\title{
UJI DAYA BUNUH EKSTRAK DAUN Acacia nilotica L. TERHADAP BAKTERI Bacillus
} subtilis dan Staphylococcus epidermidis

\author{
Syarifah Mirftahul El Jannah ${ }^{1)}, *$ Imas Latifah $^{2)}$, Zuraida $^{2)}$ \\ ${ }^{1}$ Poltekkes Kemenkes Jakarta II \\ ${ }^{2}$ Program Studi Analis Kesehatan, Fakultas Kesehatan, Universitas Mohammad Husni Thamrin \\ Correspondence author:Imas Latifah, imaslatifah72@gmail.com, Jakarta, Indonesia
}

\section{ABSTRAK}

Acacia nilotica L. adalah tumbuhan polong pengikat nitrogen serbaguna, diketahui memiliki banyak manfaatnya untuk pengobatan berbagai penyakit karena bisa bertindak sebagai antimikroba. Penelitian ini bertujuan untuk menentukan kemampuan daya bunuh ekstrak daun Acacia nilotica L. terhadap bakteri Bacillus subtilis dan Staphylococcus epidermidis. Penelitian dilakukan dengan metode turbidimetri dengan formula konsentrasi ekstrak daun Acacia nilotica L. 25\%, 20\%, 15\% dan 10\% yang diencerkan dengan pelarut DMSO 4\% dan menggunakan kontrol positif antibiotik Amoxicillin 0,75\% dengan replikasi sebanyak enam kali didapatkan hasil bahwa ekstrak daun Acacia nilotica L. mampu membunuh bakteri Bacillus subtilis pada konsentrasi ekstrak daun Acacia nilotica L. pada konsentrasi $25 \%$ dan 20\%, sedangkan untuk bakteri Staphylococcus epidermidis pada konsentrasi 25\%, 20\%, dan 15\%. Hasil pada uji ANOVA metode LSD menunjukkan adanya perbedaan signifikan kemampuan membunuh Bacillus subtilis pada konsentrasi ekstrak daun Acacia nilotica L. 25\% dengan 20\%, 15\% dan 10\%, tetapi tidak ada perbedaan signifikan pada konsentrasi 20\% dengan 15\%. Sedangkan pada Staphylococcus epidermidis adanya perbedaan signifikan kemampuan membunuh ekstrak daun Acacia nilotica L. pada masing-masing konsentrasi 25\%, 20\%, 15\% dan $10 \%$.

Kata kunci : Acacia nilotica L., Bacillus subtilis, Daya bunuh, Ekstrak daun Acacia nilotica L., Staphylococcus epidermidis, Turbidimetri.

\begin{abstract}
Acacia nilotica L. is a versatile nitrogen-fixing legume, known to have many benefits for the treatment of various diseases because it acts as an antimicrobial. This study aims to determine the killing power of Acacia nilotica L. leaf extract against Bacillus subtilis and Staphylococcus epidermidis bacteria. The research was conducted using a turbidimetric method with a concentration formula of $25 \%, 20 \%, 15 \%$ and $10 \%$ Acacia nilotica L. leaf extract diluted with $4 \%$ DMSO solvent and using a positive control antibiotic Amoxicillin $0.75 \%$ with replication six times, the results showed that Acacia nilotica L. leaf extract was able to kill Bacillus subtilis at a concentration of Acacia nilotica L. leaf extract at a concentration of $25 \%$ and $20 \%$, while for Staphylococcus epidermidis bacteria at a concentration of $25 \%, 20 \%$, and $15 \%$. The results of the LSD method ANOVA test showed that there was a significant difference in the ability to kill Bacillus subtilis at the concentration of 25\% Acacia nilotica L. leaf extract with $20 \%, 15 \%$ and $10 \%$, but there was no significant difference at the concentration of $20 \%$ and $15 \%$. Whereas in Staphylococcus epidermidis, there was a significant difference in the ability to kill Acacia nilotica L. leaf extract at 25\%,20\%, 15\% and 10\% concentrations respectively.
\end{abstract}

Keywords: Acacia nilotica L., Bacillus subtilis, Killing power, Acacia nilotica L. leaf extract, Staphylococcus epidermidis, Turbidimetry 


\section{PENDAHULUAN}

Bakteri merupakan salah satu mikroorganisme utama penyebab terjadinya beberapa penyakit infeksi (Mitchell et al., 2006). Bakteri dapat menimbulkan infeksi dengan masuk ke dalam tubuh, bertahan hidup, berlipat ganda, dan mengganggu fungsi normal sel (Parker, 2009).

Bacillus subtilis dan Staphylococcus epidermidis adalah spesies dari Gram-positif, dengan Bacillus subtilis berbentuk batang sedangkan Staphylococcus epidermidis berbentuk bulat, dan bersifat komensal yang tersebar luas di alam, baik di tanah, air, tumbuhan, hewan maupun tanaman yang dapat menyerang manusia dan menyebabkan berbagai macam infeksi baik dalam sistem menyerang individu dengan sistem kekebalan tubuh yang lemah,saluran cerna maupun bertindak sebagai bakteri nosokomial.

Indonesia merupakan negara yang kaya akan sumber daya alam. Indonesia disebut sebagai negara yang memiliki tanah subur dan banyak memiliki keanekaragaman hayati yang melimpah. Berbagai jenis tanaman ada di indonesia salah satunya adalah tanaman obat atau herbal, mulai dari jenis rimpang, batang, daun maupun jenis herbal lainnya (Pranata, 2014).

Sebanyak 40.000 jenis flora yang tumbuh didunia 30.000 jenis flora diantaranya tumbuh di Indonesia salah satunya adalah tanaman Acacia nilotica L. (Litbang Depkes, 2009).

Acacia nilotica L. adalah tumbuhan polong pengikat nitrogen serbaguna. Hal ini terjadi dari permukaan laut hingga lebih dari $200 \mathrm{~m}$ dan tanah suhu ekstrim $\left(>50^{\circ} \mathrm{C}\right)$ dan kekeringan udara, tetapi sensitif terhadap embun beku ketika masih muda (Kiran dan Bargali, 2009).

Tumbuhan Acacia nilotica L. biasa disebut Gum Arab atau Babul dan termasuk family Fabaceae yang memiliki aktivitas antimikroba (Ariani, 2013). Penelitian ini dilakukan oleh Sharma, et al (2014:52) membuktikan ekstrak etanol daun Acacia nolotica L. memiliki kandungan steroid, saponin, tannin, dan flavonoid. Penelitian yang juga dilakukan oleh Ariani tahun 2013, identifikasi fitokimia pada ekstrak daun Acacia nilotica L. menunjukkan adanya kandungan senyawa saponin, tannin, flavonoid. Penelitian tentang ekstrak etanol daun Acacia nilotica L. untuk menghambat pertumbuhan bakteri dilakukan oleh Ariani tahun 2013. Bakteri yang digunakan Bacillus subtilis dan Escherichia coli. 
Dengan demikian berdasarkan hasil tersebut belum diketahui konsentrasi bunuh minimal sehingga peneliti tertarik untuk menguji tentang ekstrak daun Acacia nilotica L. sebagai antibakteri dalam membunuh Bacillus subtilis dan Staphylococcus epidermidis.

Acacia nilotica L. mempunyai banyak manfaat untuk pengobatan, sehingga mendorong peneliti untuk melakukan penelitian menggunakan daun Acacia nilotica L., untuk mengetahui apakah ekstrak daun Acacia nilotica L. berpengaruh terhadap pertumbuhan bakteri Bacillus subtilis dan Staphylococcus epidermidis yang dapat menyebabkan berbagai macam infeksi bagi manusia.

\section{METODE}

Penelitian dilakukan pada 14 Juli-12 September 2019 di Laboratorium Mikrobiologi Universitas M.H Thamrin. Populasi yang digunakan pada penelitian ini adalah daun Acacia nilotica L. dengan usia 1 tahun yang diperoleh dari Taman Nasional Baluran, Jawa Timur dan sampel adalah ekstrak daun Acacia nilotica L. yang berwarna hijau, dengan dibuat konsentrasi 25\%, 20\%, 15\%, 10\%. Pengekstrak daun Acacia nilotica L. dengan etanol 96\% yang dilakukan di Balitro, Bogor Jawa Barat. pengenceran ekstrak daun Acacia nilotica L. dengan pelarut DMSO 25\%, dengan berbagai konsentrasi. dilakukan uji daya bunuh dengan metode dilusi (turbidimetri) terhadap bakteri dengan replikasi sebanyak enam kali. diukur absorban konsentrasi minimum ekstrak daun Acacia nilotica L. setelah dilakukan inkubasi pada suhu $37^{\circ} \mathrm{C}$ selama 24 jam.

\section{HASIL DAN PEMBAHASAN}

Hasil pengamatan uji daya bunuh Ekstrak Daun Acacia nilotica L. terhadap bakteri Bacillus subtilis dan Staphylococcus epidermidis dibaca berdasarkan kekeruhan yang diketahui melalui nilai absorbance pada spektrofotometer.

Pada penelitian ini dilakukan dengan beberapa kali uji pendahuluan untuk menemukan konsentrasi

yang tepat sehingga ekstrak daun Acacia nilotica L. dinyatakan dapat membunuh bakteri Staphylococcus epidermidis dan Bacillus subtilis. 
Pembuktian akan terjadinya kemampuan membunuh bakteri dibuktikan dengan menanamkan isolat kuman yang telah kontak selama 24 jam dengan ekstrak daun Acacia nilotica L. Penanaman dilakukan sebanyak $10 \mu$ pada agar plate MHA..

Didapatkan hasil yang sudah baik maka dilakukan replikasi/pengulangan sebanyak 6 (enam) kali dengan konsentrasi 25\%, 20\%, 15\%, 10\% dan DMSO 25\%.

Tabel 1.

Hasil absorbans menggunakan konsentrasi ekstrak daun Acacia nilotica L. 25\%, 20\%, 15\% dan 10\% dan antibitotik (Amoxicillin) 0,75\%.dengan DMSO 25\% pada bakteri Bacillus subtilis.

\begin{tabular}{cccccccccc}
\hline & \multicolumn{7}{c}{ Absorbans } \\
\hline \multirow{2}{*}{$\begin{array}{c}\text { KONSENTRASI } \\
\text { EKSTRAK(\%) }\end{array}$} & $\begin{array}{c}\text { WAKTU } \\
\text { INKUBASI } \\
\text { (JAM) }\end{array}$ & 1 & 2 & 3 & 4 & 5 & 6 & $\begin{array}{c}\text { Rata- } \\
\text { rata }\end{array}$ \\
\cline { 3 - 9 } 20 & 0 & 1,247 & 1,443 & 1,641 & 1,285 & 1,265 & 1,286 & 1.361 \\
& 24 & 0,144 & 0,117 & 0,113 & 0,348 & 0,297 & 0,297 & 0.219 \\
\hline \multirow{2}{*}{$20 \%$} & 0 & 1,025 & 0,880 & 0,882 & 1,017 & 1,103 & 1,130 & 1.006 \\
& 24 & 0,247 & 0,165 & 0,226 & 0,153 & 0,050 & 0,245 & 0.181 \\
\hline \multirow{2}{*}{$15 \%$} & 0 & 0,609 & 0,657 & 0,821 & 0,782 & 0,803 & 0,743 & 0.736 \\
& 24 & 0,023 & 0,031 & 0,092 & 0,044 & 0,056 & 0,044 & 0.048 \\
\hline \multirow{2}{*}{$10 \%$} & 0 & 0,403 & 0,460 & 0,499 & 0,408 & 0,468 & 0,449 & 0.448 \\
& 24 & 0,092 & 0,056 & 0,043 & 0,050 & 0,018 & 0,019 & 0.046 \\
\hline \multirow{2}{*}{ KONTROL Positif } & 0 & 0,000 & 0,000 & 0,000 & 0,000 & 0,000 & 0,000 & 0.000 \\
& 24 & 0,082 & 0,069 & 0,064 & 0,050 & 0,090 & 0,067 & 0.070 \\
\hline \multirow{2}{*}{ KONTROL } & 0 & 0,000 & 0,000 & 0,000 & 0,000 & 0,000 & 0,000 & 0.000 \\
Negatif & 24 & 0,154 & 0,208 & 0,426 & 0,180 & 0,164 & 0,210 & 0.224 \\
\hline
\end{tabular}

(Sumber: Data Primer)

Agar lebih jelas penurunan absorbans dari masing-masing konsentrasi dapat dilihat pada Gambar 10 dibawah ini.

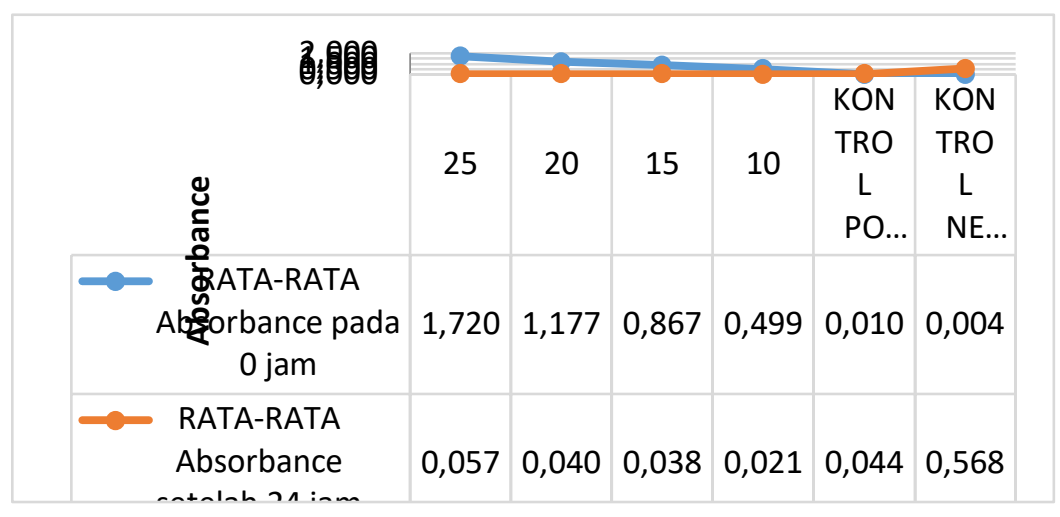

Gambar 10.

Grafik penurunan absorbans pada konsentrasi ekstrak daun Acacia nilotica L. 25\%, 20\%, 15\%,10\%, dan kenaikan pada kontrol positif dan kontrol negatif pada bakteri Bacillus subtilis .

(Sumber: Data Primer) 
Pembuktian akan terjadinya kemampuan membunuh bakteri dibuktikan dengan menanamkan isolat kuman yang telah kontak selama 24 jam dengan ekstrak daun Acacia nilotica L. Penanaman dilakukan sebanyak $10 \mu$ pada agar plate MHA.. Hasil pertumbuhan dapat dilihat pada Tabel 10.

Tabel 10.

Jumlah koloni Bacillus subtilis pada media Mueller Hinton Agar (MHA). setelah kontak 24 jam dengan ekstrak daun Acacia nilotica $\mathrm{L}$

konsentrasi $25 \%, 20 \%, 15 \%$ dan $10 \%$.

\begin{tabular}{ccccccc}
\hline \multicolumn{7}{c}{ Jumlah Koloni pada Media MHA } \\
\hline \hline \multirow{2}{*}{ KONSENTRASI EKSTRAK (\%) } & 1 & 2 & 3 & 4 & 5 & 6 \\
\cline { 2 - 8 } & 0 & 0 & 0 & 0 & 0 & 0 \\
\hline $25 \%$ & 0 & 0 & 0 & 0 & 0 & 0 \\
\hline $20 \%$ & 2 & 1 & 2 & 2 & 1 & 2 \\
\hline $15 \%$ & $>300$ & $>300$ & $>300$ & $>300$ & $>300$ & $>300$ \\
\hline $10 \%$ & $>300$ & $>300$ & $>300$ & $>300$ & $>300$ & $>300$ \\
\hline Kontrol Positif (Amoxicillin 0,75\%) & $>300$ & $>300$ & $>300$ & $>300$ & $>300$ & $>300$ \\
\hline Kontrol Negatif (DMSO 25\%) & & & & & & \\
\hline
\end{tabular}

(Sumber: Data Primer)

Tabel 11.

Hasil absorbans menggunakan konsentrasi ekstrak daun Acacia nilotica L. 25\%, 20\%, 15\% dan 10\% dan antibitotik (Amoxicillin) 0,75\%.dengan DMSO 25\% pada bakteri Staphylococcus epidermidis.

\begin{tabular}{cccccccc|c}
\hline \multicolumn{10}{c}{ Absorban 670 nm } \\
\hline \multirow{2}{*}{$\begin{array}{c}\text { KONSENTRASI } \\
\text { EKSTRAK (\%) }\end{array}$} & $\begin{array}{c}\text { WAKTU } \\
\text { INKBASI } \\
\text { (JAM) }\end{array}$ & 1 & 2 & 3 & 4 & 5 & 6 & $\begin{array}{c}\text { Rata- } \\
\text { rata }\end{array}$ \\
\cline { 3 - 10 } $25 \%$ & 0 & 1,778 & 1,685 & 1,719 & 1,673 & 1,832 & 1,632 & 1.720 \\
& 24 & 0,089 & 0,052 & 0,012 & 0,077 & 0,086 & 0,023 & 0.057 \\
\hline \multirow{2}{*}{$20 \%$} & 0 & 1,079 & 1,326 & 1,209 & 1,013 & 1,117 & 1,318 & 1.177 \\
& 24 & 0,030 & 0,113 & 0,034 & 0,005 & 0,012 & 0,043 & 0.040 \\
\hline \multirow{2}{*}{$15 \%$} & 0 & 0,704 & 0,918 & 0,937 & 0,885 & 0,893 & 0,864 & 0.867 \\
& 24 & 0,009 & 0,075 & 0,062 & 0,005 & 0,069 & 0,007 & 0.038 \\
\hline \multirow{2}{*}{$10 \%$} & 0 & 0,466 & 0,523 & 0,506 & 0,501 & 0,479 & 0,517 & 0.499 \\
& 24 & 0,029 & 0,014 & 0,021 & 0,517 & 0,012 & 0,033 & 0.104 \\
\hline KONTROL & 0 & 0,007 & 0,013 & 0,000 & 0,024 & 0,011 & 0,007 & 0.010 \\
Positif & 24 & 0,040 & 0,040 & 0,047 & 0,039 & 0,039 & 0,059 & 0.044 \\
\hline KONTROL & 0 & 0,002 & 0,010 & 0,001 & 0,000 & 0,011 & 0,000 & 0.004 \\
Negatif & 24 & 0,498 & 0,468 & 0,476 & 0,615 & 0,679 & 0,674 & 0.568 \\
\hline
\end{tabular}

(Sumber: Data Primer)

Agar lebih jelas penurunan absorbans dari masing-masing konsentrasi dapat dilihat pada

Gambar 12 dibawah ini. 


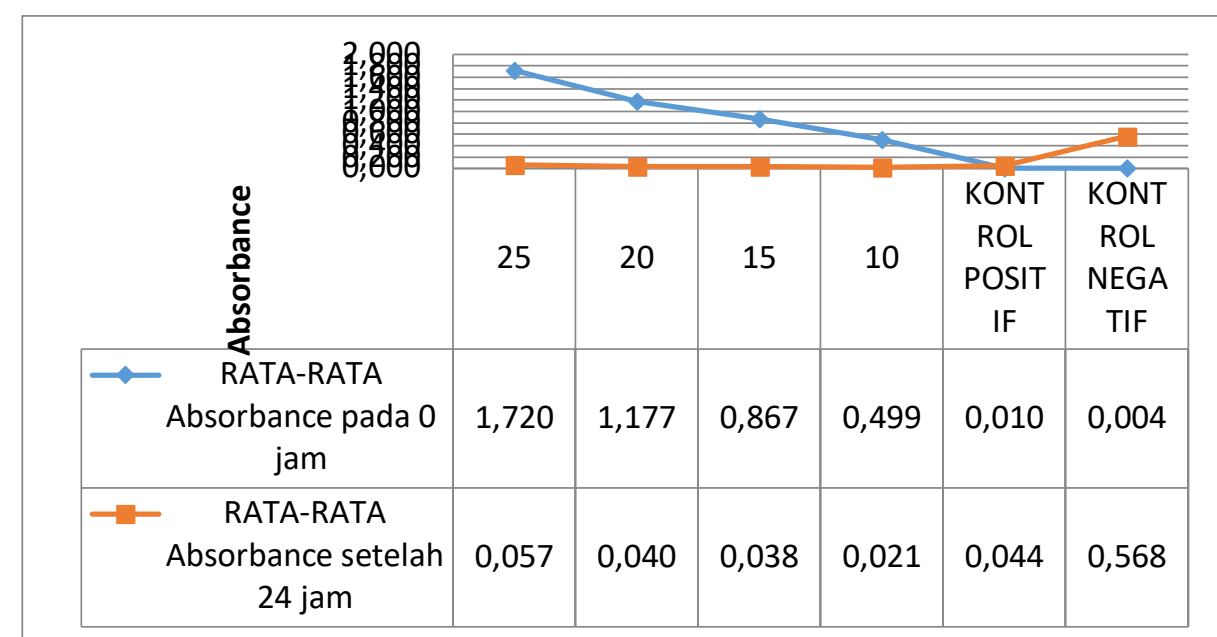

Gambar 12.

Grafik penurunan absorbans pada konsentrasi ekstrak daun Acacia nilotica L. 25\%, 20\%, 15\%,10\%, dan kenaikan pada kontrol positif dan kontrol negatif pada bakteri Staphylococcus epidermidis .

(Sumber: Data Primer)

Pembuktian akan terjadinya kemampuan membunuh bakteri dibuktikan dengan menanamkan isolat kuman yang telah kontak selama 24 jam dengan ekstrak daun Acacia nilotica L. Penanaman dilakukan sebanyak $10 \mu$ pada agar plate MHA.. Hasil pertumbuhan dapat dilihat pada Tabel 12.

Tabel 12.

Jumlah koloni Staphylococcus epidermidis pada media Mueller Hinton Agar (MHA). setelah kontak 24 jam dengan ekstrak daun Acacia nilotica L konsentrasi 25\%, 20\%, 15\% dan 10\%.

\begin{tabular}{ccccccc}
\hline \multicolumn{7}{c}{ Jumlah Koloni pada Media MHA } \\
\hline \multicolumn{7}{c}{ Staphylococcus epidermidis } \\
\hline \multirow{2}{*}{ KONSENTRASI EKSTRAK $(\%)$} & 1 & 2 & 3 & 4 & 5 & 6 \\
\hline $25 \%$ & 0 & 0 & 0 & 0 & 0 & 0 \\
\hline $20 \%$ & 0 & 0 & 0 & 0 & 0 & 0 \\
\hline $15 \%$ & 0 & 0 & 0 & 0 & 0 & 0 \\
\hline $10 \%$ & $>300$ & $>300$ & $>300$ & $>300$ & $>300$ & $>300$ \\
\hline Kontrol Positif (Amoxicillin 0,75\%) & $>300$ & $>300$ & $>300$ & $>300$ & $>300$ & $>300$ \\
\hline Kontrol Negatif (DMSO 25\%) & $>300$ & $>300$ & $>300$ & $>300$ & $>300$ & $>300$ \\
\hline
\end{tabular}

(Sumber: Data Primer)

Berdasarkan Tabel 9, 10, 11 dan 12, Gambar 10, 11, 12 dan 13. Untuk bakteri Staphylococcus epidermidis dan Bacillus subtilis hasil menujukkan konsentrasi absorban dari 0 jam ke 24 jam adanya penurunan pada konsentrasi 25\%, 20\%, 15\%, 10\% dan hasil Staphylococcus epidermidis pada media plate MHA terjadi daya bunuh terlihat pada konsentrasi $25 \%, 20 \%$ dan $15 \%$. Sedangkan hasil dari bakteri Bacillus subtilis menunjukkan adanya daya bunuh dari media plate MHA pada konsentrasi 
$25 \%$ dan $20 \%$ Menganalisa kemampuan daya bunuh berdasarkan konsentrasi ekstrak daun Acacia nilotica L. terhadap bakteri Bacillus subtilis dan Staphylococcus epidermidis. Kemampuan daya bunuh ekstrak daun Acacia nilotica L. secara angka terlihat perbedaan, untuk membuktikan bahwa apakah ada perbedaan yang nyata dari masing-masing konsentrasi tersebut dilakukan uji ANOVA metode LSD sehingga di dapatkan hasil seperti ini pada Tabel 13 dan Tabel 14.

Tabel 13.

Perbedaan daya bunuh ekstrak daun Acacia nilotica L terhadap pertumbuhan bakteri Bacillus subtilis berdasarkan konsentrasi.

\begin{tabular}{|c|c|c|c|c|c|c|}
\hline \multirow{2}{*}{$\stackrel{(\mathrm{I})}{\text { Konsentrasi }}$} & \multirow{2}{*}{$\begin{array}{c}(\mathrm{J}) \\
\text { Konsentrasi }\end{array}$} & \multirow{2}{*}{$\begin{array}{c}\text { Mean } \\
\text { Difference } \\
(\mathrm{I}-\mathrm{J})\end{array}$} & \multirow[t]{2}{*}{ Std. Error } & \multirow[t]{2}{*}{ Sig. } & \multirow{2}{*}{$\begin{array}{c}95 \% \\
\text { Confidence } \\
\text { Interval } \\
\text { Lower } \\
\text { Bound } \\
\end{array}$} & \\
\hline & & & & & & $\begin{array}{l}\text { Upper } \\
\text { Bound }\end{array}$ \\
\hline \multirow[t]{3}{*}{$\mathrm{K} 25 \%$} & K 20\% & $.3166667^{*}$ & .0836356 & .001 & .142206 & .491127 \\
\hline & $\mathrm{K} 15 \%$ & $.4543333^{*}$ & .0836356 & .000 & .279873 & .628794 \\
\hline & K10\% & $.7371667 *$ & .0836356 & .000 & .562706 & .911627 \\
\hline \multirow[t]{3}{*}{ K 20\% } & K25\% & $-.3166667 *$ & .0836356 & .001 & -.491127 & -.142206 \\
\hline & K15\% & .1376667 & .0836356 & .115 & -.036794 & .312127 \\
\hline & K10\% & $.4205000 *$ & .0836356 & .000 & .246039 & .594961 \\
\hline \multirow[t]{3}{*}{ K15\% } & K25\% & $-.4543333 *$ & .0836356 & .000 & -.628794 & -.279873 \\
\hline & K 20\% & -.1376667 & .0836356 & .115 & -.312127 & .036794 \\
\hline & $\mathrm{K} 10 \%$ & $.2828333 *$ & .0836356 & .003 & .108373 & .457294 \\
\hline \multirow[t]{3}{*}{$\mathrm{K} 10 \%$} & K25\% & $-.7371667 *$ & .0836356 & .000 & -.911627 & -.562706 \\
\hline & K 20\% & $-.4205000^{*}$ & .0836356 & .000 & -.594961 & -.246039 \\
\hline & K15\% & $-.2828333^{*}$ & .0836356 & .003 & -.457294 & -.108373 \\
\hline
\end{tabular}

*The mean difference is significant at the 0.05 level.

(Sumber: Data Primer)

Tabel 14.

Perbedaan daya bunuh ekstrak daun Acacia nilotica L terhadap pertumbuhan bakteri Staphylococcus epidermidis

berdasarkan konsentrasi.

\begin{tabular}{|c|c|c|c|c|c|c|}
\hline \multirow{2}{*}{\multicolumn{2}{|c|}{$\begin{array}{l}\text { (I) } \\
\text { KONSENTRASII }\end{array}$}} & \multirow{2}{*}{$\begin{array}{l}\text { Mean } \\
\text { Difference (I- } \\
\text { J) }\end{array}$} & \multirow[b]{2}{*}{ Std. Error } & \multirow[b]{2}{*}{ Sig. } & \multicolumn{2}{|c|}{ 95\% Confidence Interval } \\
\hline & & & & & Lower Bound & Upper Bound \\
\hline \multirow{3}{*}{$\mathrm{K} 25 \%$} & K20\% & $.5258333^{*}$ & 0,0674080 & 0,000 & 0,385223 & 0,666444 \\
\hline & K15\% & $.8343333^{*}$ & 0,0674080 & 0,000 & 0,693723 & 0,974944 \\
\hline & $\mathrm{K} 10 \%$ & $1.2636667^{*}$ & 0,0674080 & 0,000 & 1,123056 & 1,404277 \\
\hline \multirow{3}{*}{ K $20 \%$} & $\mathrm{~K} 25 \%$ & $-.5258333^{*}$ & 0,0674080 & 0,000 & $-0,666444$ & $-0,385223$ \\
\hline & $\mathrm{K} 15 \%$ & $.3085000^{*}$ & 0,0674080 & 0,000 & 0,167889 & 0,449111 \\
\hline & $\mathrm{K} 10 \%$ & $.7378333^{*}$ & 0,0674080 & 0,000 & 0,597223 & 0,878444 \\
\hline \multirow{3}{*}{$\mathrm{K} 15 \%$} & $\mathrm{~K} 25 \%$ & $-.8343333^{*}$ & 0,0674080 & 0,000 & $-0,974944$ & $-0,693723$ \\
\hline & $\mathrm{K} 20 \%$ & $-.3085000^{*}$ & 0,0674080 & 0,000 & $-0,449111$ & $-0,167889$ \\
\hline & $\mathrm{K} 10 \%$ & $.4293333^{*}$ & 0,0674080 & 0,000 & 0,288723 & 0,569944 \\
\hline \multirow{3}{*}{$\mathrm{K} 10 \%$} & K25\% & $-1.2636667^{*}$ & 0,0674080 & 0,000 & $-1,404277$ & $-1,123056$ \\
\hline & $\mathrm{K} 20 \%$ & $-.7378333^{*}$ & 0,0674080 & 0,000 & $-0,878444$ & $-0,597223$ \\
\hline & $\mathrm{K} 15 \%$ & $-.4293333^{*}$ & 0,0674080 & 0,000 & $-0,569944$ & $-0,288723$ \\
\hline
\end{tabular}

*. The mean difference is significant at the 0.05 level. 
(Sumber: Data Primer)

Berdasarkan Tabel 13 dan 14, dengan alfa 0,05 pada bakteri Bacillus subtilis didapatkan p-value sebesar 0,003 $(p<0,05)$ dan pada bakteri Staphylococcus epidermidis didapatkan $p$-value sebesar 0,000 $(p<0,05)$ sehingga menunjukkan adanya perbedaan kemampuan daya bunuh ekstrak daun Acacia nilotica $\mathrm{L}$. dari masing-masing konsentrasi.

Jadi ada perbedaan signifikan kemampuan membunuh Bacillus subtilis pada konsentrasi ekstrak daun Acacia nilotica L. $25 \%$ dengan $20 \%, 15 \%$ dan 10\%, tetapi tidak ada perbedaan kemampuan membunuh ekstrak daun Acacia nilotica L. pada konsentrasi 20\% dengan 15\%. Sedangkan pada Staphylococcus epidermidis adanya perbedaan signifikan kemampuan membunuh ekstrak daun Acacia nilotica L. pada masing-masing konsentrasi $25 \%$ dengan $20 \%, 15 \%$ dan $10 \%$, yang mana semakin tinggi/pekat konsentrasi ekstrak daun Acacia nilotica L. semakin besar juga daya bunuhnya.

konsentrasi ekstrak daun Acacia nilotica L. dalam membunuh Bacillus subtilis dan Staphylococcus epidermidis. Penelitian ini menggunakan metode turbidimetri dengan bakteri Bacillus subtilis dan Staphylococcus epidermidis dengan menggunakan media cair Mueller Hinton Broth (MHB) dan untuk media platenya menggunakan media Mueller Hinton Agar (MHA).

Dalam penelitian ini daun Acacia nilotica L. diekstraksi dengan pelarut etanol 96\% sehingga dapat menarik bahan aktif yang terkandung didalam daun Acacia nilotica L. yaitu alkaloid,flavonoid, saponin, steroid, tanin, minyak atsri dan fenol (Pradipta, 2016) .

Berdasarkan hasil pengamatan yang dilakukan sebanyak 6 (enam) kali pengulangan pada absorban maupun media plate MHA. Pada media cair (MHB), bakteri Bacillus subtilis dan Staphylococcus epidermidis terjadinya kekeruhan yang sangat keruh dikonsentrasi Kontrol positif dan Kontrol negatif sedangkan dikonsentrasi $25 \%, 20 \%, 15 \%$ dan $10 \%$ terjadi kekeruhan ringan. Pada bakteri Bacillus subtilis dimedia plate MHA didapatkan hasil tidak ada pertumbuhan koloni dikonsentrasi $25 \%$ dan $20 \%$, sedangkan dikonsentrasi $15 \%, 10 \%$, kontrol positif dan kontrol negatif didapat hasil koloni berjumlah $>300$ koloni. Dan pada bakteri Staphylococcus epidermidis dimedia plate MHA didapatkan hasil tidak ada pertumbuhan koloni dikonsentrasi 25\%, 20\% dan 15\%. Sedangkan dikonsentrasi 10\%, kontrol positif dan kontrol negatif didapat hasil koloni berjumlah $>300$ koloni. 
Tidak terjadinya kekeruhan/jernih menunjukan kemampuan antibiotik atau zat antibakteri dalam membunuh bakteri Bacillus subtilis dan Staphylococcus epidermidis. Tetapi hasil yang didapat pada kontrol positif (Amoxicillin) terbentuknya kekeruhan yang sangat keruh, dikarenakan antibiotik dan pelarut yang digunakan tidak sesuai dengan standar farmakope.

Penelitian ini dilakukan pengenceran terhadap ekstrak daun Acacia nilotica L. dengan pelarut 25\% sehingga zat aktif yang terkandung pada masing-masing konsentrasi tidak sama banyak dan semakin menurun seiring dengannya menurunnya konsentrasi ekstrak. Kontrol positif yang digunakan yaitu Amoxicillin yang digunakan sebagai kontrol positif di bakteri Bacillus subtilis dan Staphylococcus epidermidis dengan mekanisme memiliki spectrum antibiotik yang luas terhadap bakteri Gram positif dan Gram negatif pada manusia maupun hewan (Kaue et al., 2011).

Bahan aktif yang terkandung dalam ekstrak daun Acacia nilotica L. dapat memberikan efek antibakteri dengan mekanisme yang berbeda-beda. Saponin merupakan produk glikosida alam dengan berat molekul tinggi yang memiliki kemampuan antibakteri dengan memberikan perlindungan terhadap patogen potensial dan akan mengganggu tegangan permukaan dinding sel (Majidah, 2014). Alkaloid merupakan golongan zat tumbuhan sekunder yang terbesar. Alkaloid memiliki kemampuan sebagai antibakteri, mekanisme sebagai senyawa antibakteri adalah dengan cara mengganggu komponen penyusun peptidoglikan pada sel bakteri, sehingga lapisan dinding sel tidak terbentuk secara utuh dan menyebabkan kematian sel (Rijayanti, 2014). Flavonoid

Flavonoid merupakan kumpulan dari polifenol yang terdiri dari lima belas karbon dan dua cincin aromatik yang dihubungkan oleh tiga rantai karbon. Mekanisme kerja antibakteri flavonoid ada tiga macam yaitu dengan cara menghambat sintesis asam nukleat, menghambat fungsi membran sitoplasma dan menghambat metabolisme energi (Majidah, 2014).

Mekanisme kerja antibakteri senyawa steroid yaitu dengan cara merusak membran lipid sel bakteri sehingga permeabilitas sel terganggu dan selnya mengalami lisis yang menyebabkan semua materi isi sel keluar sehingga sel tidak dapat difungsikan lagi (Rijayanti, 2014). Minyak atsiri 
Mekanisme minyak atsiri sebagai antibakrteri adalah dengan merusak dinding sel bakteri. Minyak atsiri memiliki daya antiseptik lima kali lebih kuat dibandingkan fenol biasa (Bakterisid dan Fungisid) tetapi tidak sporasid (Carolia and Noventi, 2016).

Berdasarkan pada Tabel 13 dan Tabel 14, hasil menunjukkan terjadinya daya bunuh yang terbentuk dari seiringn kenaikan konsentrasi ektrak daun Acacia nilotica L. yang digunakan. Hal ini diakibatkan karena perbedaan kadar ekstrak daun Acacia nilotica L. dalam setiap suspensi ekstrak, semakin tinggi konsentrasi maka kadar ekstrak yang terkandung dalam suspensi akan semakin tinggi sehingga bahan aktif yang terdapat didalam ekstrak daun Acacia nilotica L. semakin tinggi pula kemampuan daya bunuh. Hasil penelitian ini menghasilkan daya bunuh terhadap bakteri Bacillus subtilis dan Staphylococcus epidermidis.

Bacillus subtilis adalah bakteri berspora tetapi karena pada uji ini digunakan bakteri yang usia dalam 24 jam, kemudian situasi makanan dan kondisi lingkungan yang baik, maka spora tidak terbentuk sehingga bakteri Bacillus subtilis bisa langsung terbunuh oleh senyawa aktif yang terkandung didalam ekstrak daun Acacia nilotica L. dan untuk bakteri Stahylococcus epidermidis karena bakteri tersebut tidak memiliki spora jadi akan lebih sangat mudah dibunuh oleh senyawa aktif yang terkandung didalam ekstrak daun Acacia nilotica L. Untuk bakteri Gram positif akan lebih mudah mengalami kematian/dibunuh. Maka ekstrak daun Acacia nilotica L. ini mampu membunuh bakteri Gram positif. Hasil uji ANOVA metode LSD berdasarkan Tabel 10 dan 11, dengan alfa 0,05 pada bakteri Bacillus subtilis didapatkan $p$-value sebesar 0,003 $(p<0,05)$ dan pada bakteri Staphylococcus epidermidis didapatkan $p$-value sebesar $0,000(p<0,05)$ sehingga menunjukkan adanya perbedaan kemampuan daya bunuh ekstrak daun Acacia nilotica L. dari masing-masing konsentrasi.

Jadi ada perbedaan signifikan kemampuan membunuh Bacillus subtilis pada konsentrasi ekstrak daun Acacia nilotica L. $25 \%$ dengan $20 \%$, $15 \%$ dan $10 \%$, tetapi tidak ada perbedaan kemampuan membunuh ekstrak daun Acacia nilotica L. pada konsentrasi 20\% dengan 15\%. Sedangkan pada Staphylococcus epidermidis adanya perbedaan signifikan kemampuan membunuh ekstrak daun Acacia nilotica L. pada masing-masing konsentrasi $25 \%$ dengan $20 \%$, $15 \%$ dan $10 \%$, yang mana semakin tinggi/pekat konsentrasi ekstrak daun Acacia nilotica L. semakin besar juga daya bunuhnya. 


\section{SIMPULAN}

Terdapat perbedaan signifikan terhadap masing-masing konsentrasi kemampuan daya bunuh pada ekstrak daun Acacia nilotica L. didapatkan hasil perbedaan signifikan terhadap bakteri Bacillus subtilis pada konsentrasi $25 \%$ dengan 20\%, 15\% dan $10 \%$. Sedangkan pada konsentrasi $20 \%$ adanya perbedaan signifikan pada konsentarsi $25 \%$ dan $10 \%$, tetapi terhadap konsentrasi $15 \%$ tidak adanya perbedaan signifikan. Dan pada konsentrasi $15 \%$ adanya perbedaan signifikan pada konsentrasi $25 \%$ dan $10 \%$, tetapi pada konsentrasi 20\% tidak adanya perbedaan signifikan. Dan untuk konsentrasi $10 \%$ adanya perbedaan signifikan antara 25\%, 20\% dan 15\% (pada semua konsentrasi). Untuk bakteri Staphylococcus epidermidis terdapat adanya perbedaan signifikan pada semua konsentrasi kemampuan daya bunuh ekstrak daun Acacia nilotica L. antara konsentrasi 25\%, dengan 20\%, 15\% dan 10\% (pada masing-masing konsentrasi memiliki perbedaan signifikan)

\section{UCAPAN TERIMA KASIH}

Penulis mengucapkan terima kasih kepada Panti Sosial Tresna werdha Budi Mulia 1 Cipayung Jakarta Timur dan Prodi D III Analis Kesehatan Universitas MH Thamrin berperan serta dalam penelitian ini.

\section{DAFTAR PUSTAKA}

1. Amjad, ur Rahman Abdul, Shakoor Gul, Zaib Abdul, Samad Mumtaz Yasir, Ihtesham Abdul, Aziz Napar (2014) 'Comparative antimicrobial activity of Acacia nilotica L. leaves extracts against pathogenic bacteria and fungi', Journal of Medicinal Plants Research. doi: $10.5897 /$ jmpr2012.354.

2. Ariani, A. 2013 "Saponin Akasia Berduri (Acacia nilotica L.) Sebagai Pembusa Alami dan Agnesia Antibakteri dalam Sabun Cair”. Tidak Diterbitkan Tugas Akhir. Salatiga: Fakultas Sains dan Matematika, Universitas Kristen Satya Wacana.

3. Balitro (Badan Penelitian Tanaman Rempah dan Obat). (2018). Standar Operasional Prosedure Pembuatan Ekstrak daun Acacia nilotica L dengan pelarut Etanol 96\%. Bogor.

4. Bargali, K. and Bargali, S. S. (2009) 'Acacia nilotica: a multipurpose leguminous plant', Nature and Science, 7(4), pp. 11-19.

5. Basari, Z. (2012) 'Teknik Pembongkaran Tumbuhan Invasif Acacia Nilotica (L) Willd. Ex. Del Dengan Tirfor Di Taman Nasional Baluran Jawa Timur', Jurnal Penelitian Hasil Hutan. Forestry Research, Development and Innovation Agency, 30(4), pp. 279-290.

6. Djufri, 2011. Pengaruh Tegakan Akasia (Acacia nilotica L.) Willd. Ex. Del. Terhadap Komposisi dan Keanekaragaman Tumbuhan Bawah Di Savana Balanan Taman Nasional Baluran Jawa Timur" Jurnal Ilmiah Pendidikan Biologi, Biologi Edukasi. Vul.3 (2): 1-50.

Open Journal System (OJS): journal.thamrin.ac.id 
7. Ehrenberg, CG (1835). Physikalische Abhandlungen der Koeniglichen Akademie der Wissenschaften zu Berlin aus den Jahren 1833-1835. hlm. 145-336.

8. Euzéby, JP (2008). "Bacillus". List of Prokaryotic names with Standing in Nomenclature. Diarsipkan dari versi asli tanggal 14 December 2008. Diakses tanggal 2008-11-18.

9. Jannah, Miftahul. (2018).Dokumen Pribadi.

10. Jawetz, E. 2005. Mikrobiologi Untuk Profesi Kesehatan, Edisi 16. Jakarta: Salemba Medika.

11. Jodi A. Lindsay (2008). Staphylococcus: molecular genetics. Caister Academic Press. ISBN 9781-904455-29-5. Page.

12. Khunaifi, M. (2010) 'Uji aktivitas antibakteri ekstrak daun binahong (Anredera cordifolia (Ten) Steenis) terhadap bakteri Staphylococcus aureus dan Pseudomonas aeruginosa'. Universitas Islam Negeri Maulana Malik Ibrahim.

13. Malviya, S., Rawar, S., Khaira, A., dan Verma, M. 2011. Medicinal Attributes Of Acacia nilotica L. A Comprehensive Review On Enthopharmacological Claims. International Journal of Pharmacy \& Life Sciences. Vol. 2(6):830-837.

14. Pradipta, S. (2016) 'Toksisitas Campuran Ekstrak Daun Ketapang (Terminalia catappa L.) dan Daun Akasia Berduri (Acacia nilotica L.) Terhadap Mortalitas Larva Aedes aegypti L. dan Pemanfaatannya Sebagai Karya Ilmiah Populer'.

15. Teruaki Nakatsuji et al. 2018: A commensal strain of Staphylococcus epidermidis protects against skin neoplasia, in: Science Advances; Vol. 4, No. 2, DOI:10.1126/sciadv.aao4502

16. Verma, S. 2016. A Review on Enthpmedicinal Plant Acacia nilotica (Linn). Wild. Journal of Pharmacognosy and Phytochemistry. Vol. 5(2):241-242. 